\title{
THE TRANSNATIONAL GEOGRAPHIES OF IMMIGRANT POLITICS: Insights from a Comparative Study of Migrant Grassroots Organizing ${ }^{1}$
}

\author{
Patricia Landolt* \\ University of Toronto
}

\begin{abstract}
Greater global interconnectedness produces a transformation in the ways in which groups constitute and interpret the boundaries of community formation and political practice. This article considers the ways in which a group engages (or not) with the possibilities for transnational identity formation and border-crossing politics granted by the changing structures of the global order. A comparative analysis identifies similarities and differences in the patterns of community formation and political engagement of Salvadoran migrants settled across different urban centers of North America. Variations in the territorial orientation and scales of immigrant political practice are explained by the national and city-level contexts of immigrant reception, the institutional opportunity structure in which migrant groups are embedded, and the nature of relations between migrants and their migrant and nonmigrant institutional interlocutors in places of settlement and their country of origin.
\end{abstract}

Globalization is associated with a sea change in the way that groups constitute political identities and mobilize for political ends. Scholarship identifies three shifts in civil society politics including an expansion in the territorial orientation of politics to include allies and agendas situated across different nation-states (Itzigsohn and Giorguli Saucedo 2001), a greater ability to build networks that bridge distance and shift the territorial location and levels of governance within which groups make political demands (Keck and Sikkink 1998; Ostergaard-Nielsen 2003), and an extension of citizenship rights beyond the boundaries of the nation-state and into the transnational (Bauböck 1994) and supranational (Soysal 1994) sphere. These patterns suggest a shift in the way groups constitute claims to rights and recognition and a transformation in the spatiality of political practice.

In this article I examine the ways in which a group of civil society actorsSalvadoran migrants in Los Angeles, Washington, and Toronto-navigate the possibilities for community formation and political engagement in a globalizing world. Since their large-scale migration in the 1980s, the family lives and collective history of Salvadoran migrants has been marked by the cross-border circulation of people, resources, ideas, and symbols. It is a situation that lends itself but does not guarantee the formation of transnational, that is nation-state border-crossing identities and politics. It therefore

\footnotetext{
*Direct all correspondence to Patricia Landolt, Centre for Urban and Community Studies, University of Toronto, 455 Spadina Ave., Suite 400, Toronto, ON M5S 2G8, Canada; e-mail: Landolt@utsc.utoronto.ca
} 
allows me to explore how and why a group engages (or not) with the possibilities for political action granted by the changing structures of the global order. How does the transnational circulation of people, resources, ideas, and symbols play into the production of group identity and political practice?

I am particularly interested in explaining variation in the territorial orientation and socially constructed scales of migrant political practice. Exploring the spatial dimensions of transnational politics is necessary to develop a more nuanced understanding of power relations, specifically of the ways in which migrants constitute meaningful forms of political membership. The literature on transnational migration suggests that immigrant practices and normative frameworks are territorially oriented. In other words, the frame of reference for transnational practices, as indicated by the circulation of resources, ideas, and symbols, may be oriented toward people and institutions in places of origin - a transnational orientation - toward the place of settlement-an assimilationist orientation - or toward a multisited, more decentered, and potentially diasporic orientation. These orientations are not mutually exclusive (Joppke and Morawska 2003; Levitt and Glick-Schiller 2004).

However, transnational practices involve not only a crossing of borders, but also a process of "touching down" or being situated within different social locations such as the nation, the neighborhood, the village or the inherited family home. Each of these locations presumes a different type of structured interaction. Thus, transnational ties with institutions that embody the social and political concerns of the village, for instance, will be different from those that link migrants to a political party or their extended family. While recognizing the relevance of this distinction between types of border-crossing connections, transnational migration scholarship has yet to consolidate a conceptual language to make sense of this sociospatial variability. I draw on insights from geography and specifically its notion of socially constructed scales to contribute to the intellectual spadework of constituting a shared conceptual language for theorizing the transnational dimensions of political practice.

My analysis is comparative and establishes two lines of argument to explain similarities and differences in the formation of group identities and political engagement of Salvadoran migrants settled across different urban centers of North America. First, focusing on the process of community formation, I examine the ways in which national and city-level contexts of immigrant reception come together to constitute the networks and narratives that frame group identity. Second, I bridge an institutional account of political process to the concept of transnational social fields and the insights of critical geography to consider the territorial orientation and scalar dimensions of grassroots organizing activities developed by Salvadorans in Los Angeles, Washington, and Toronto. Conceptually, I develop an unbounded approach to the concept of institutional opportunity structure (IOS) to explain variation in forms of Salvadoran grassroots organizing. I also propose the concept of institutional interlocutors to provide a more dynamic account of the role of patterned dialogues between institutional actors that may potentially occur across national borders. I focus on relations between migrant organizations and other civil society actors. 
I proceed as follows. First, I provide a brief literature review. This is followed with a discussion of my comparative framework and the research methods and data. Then, I discuss the national and city-level contexts of reception that frame the process of community formation. In the fourth section I provide a sketch of the IOS that frames Salvadoran grassroots organizing. I also identify patterns of grassroots activism that exist in each settlement city and which characterize the territorial orientation and scales at which Salvadorans in Los Angeles, Washington, and Toronto engage in politics. This is followed with a concluding discussion.

\section{MAPPING THE STUDY OF IMMIGRANT POLITICS}

Two conceptual concerns organize my comparative analysis of Salvadoran grassroots activism; the first is a desire to push structural accounts of immigrant incorporation and political practice toward a more dynamic and process-oriented approach (cf. Rogers 2006), and the second is an effort to contribute to an "unbounded social science" better able to explain the growing number and variety of social relations and social formations that are constituted without propinquity.

I draw on two foundational arguments in immigration scholarship to explain crosscity variation in migrant patterns of settlement and group identity formation. First, the concept of modes of incorporation argues that variation in immigrant settlement outcomes among populations with similar demographic profiles are a result of differences in conditions of exit and contexts of reception (Portes and Böröcz 1989; Portes and Grosfoguel 1994). The literature considers contextual factors including the causes, timing, and rhythm of a migration flow (sudden versus protracted; forced or voluntary); the mechanisms of migration (the modes of travel and status upon entry); and sending country state policy, the policy response of the host government, and civil society relations with the newcomers. Settlement cities are a second-tier context of reception. A city's immigration tradition, labor market structure and political history, and its built environment, among other factors, produce a distinct local context of reception (e.g., Brettel 2003; Halle 2003). My focus on national and city-level contexts of reception captures contextual variation at different levels of analysis and allows consideration of the interplay between the two levels.

Second, institutional accounts of collective action explain variations in immigrant politics as an outcome of the interaction between the resources of a group, broadly understood in terms of human, social, and cultural capital, and the IOS. The IOS framework typically takes into account the character of state elites, government bureaucrats, and the party system to explain the rules of interaction between political allies and competitors (Schrover and Vermeulen 2005). Immigrant organizations in particular may flourish or be crowded out depending on the combination, number, and mandate of institutional actors (cf. Bloemraad 2005).

However, the institutional approach fails to specify how immigrants read the signals of a political conjuncture, learn to navigate the system, and possibly transform the political landscape (Koopmans 2005). It also emphasizes vertical contacts, typically 
between immigrants and the state or political parties, and fails to consider the impact of relations between immigrant organizations and other sectors of civil society on the formation and character of immigrant organizing. I develop the concept of institutional interlocutors to capture patterned engagement between institutional actors and focus in particular on dialogues between migrants and nonmigrant organizations in civil society. I propose the language of interlocution to emphasize the idea that mutual recognition, comprehension, and possibly a translatability of institutional concerns are required for cross-institutional relationships, even when these are guided by the most short-term and instrumental of interests.

An unbounded social science is a logical corollary to contemporary globalization and for a growing number of scholars is required to explain the character and consequences of social relations, institutions, and social formations constituted without territorial propinquity. The unbounding of the social sciences involves consideration of the spatial dimensions of social life (cf. Gieryn 2000; Kivisto 2003) and a reconfiguration of the concept of society beyond the container of the nation-state (cf. Beck 2000; Wimmer and Glick-Schiller 2003; Glick-Schiller 2005). While, the range of interventions in this theoretical endeavor is quite extraordinary my focus is on the contributions of transnational migration scholarship.

Transnational migration scholarship rests on the assumption that migration does not involve a sharp break between home and host society and that immigrants sustain significant material and symbolic ties across national-borders throughout the life cycle even as they experience assimilation in the receiving country. Early versions of the approach offered suggestive but vague spatial metaphors to capture the border-crossing social relations and institutions maintained by migrants and their nonmigrant counterparts. The language of betwixt and between, neither here nor there, with feet planted in both worlds, and simultaneity was common. The more productive refinements of the approach have come out of a focus on social networks. Faist (2000) distinguishes three levels of institutionalization based on the type, stability, and complexity of social network ties. Others have polished the concept of transnational social fields to explain the ways in which social relationships and social contexts organize processes and practices that cross the borders of nation-states (Mahler 1998; Levitt and Glick-Schiller 2004; Glick-Schiller 2005).

Transnational social fields are defined as "a set of multiple interlocking networks of social relationships through which ideas, practices and resources are unequally exchanged, organized and transformed" (Levitt and Glick-Schiller 2004:105). The concept extends the analysis of transnational migration beyond specific border-crossing practices or the direct experiences of migrants as it seeks to theorize domains of interaction without propinquity. Applied to an institutional approach to the study of immigrant politics, the concept of transnational social fields prompts an analytical shift in the boundaries drawn to delimit and characterize an IOS. Thus far, researchers have suggested that institutions such as social service agencies, state consular offices, ethnic and religious organizations, and so on frame the territorial orientation of immigrant practices. They can encourage immigrants toward the revival of ties to their country of 
origin, involvement in local affairs, commitment to multilocal and more decentered diasporic engagements, a withdrawal from any kind of politics, or a combination of these different orientations (Menjivar 1999; Kurien 2001; Gold 2002; OstergaardNielsen 2003; Levitt 2004). This leaves open the possibility that an IOS is constituted without propinquity and by extension that institutional interlocutors may sustain meaningful dialogues across borders.

Clearly, further conceptual specification of the idea of transnational domains of interaction is required. Of particular relevance to the present discussion, it is necessary to distinguish between mere personal connections and transnational connections that engage persons institutionally (cf. Glick-Schiller 2005). Institutional connections embed persons in multiple sets of rules and expectations, and presumably in more definite ways than personal contacts. I suggest that the concept of scale developed in critical geography may allow for a greater specification of the ways in which transnational institutional connectedness is different from person-to-person connections.

Space comprises the socially produced grids and horizons of social life (Lefebvre 1991; Jessop 2005). In particular, the concept of scale has traditionally been used interchangeably with that of levels (e.g., the local, regional or national level). Recently, however, geographers have turned away from the notion of scale as a fixed, bounded, self-enclosed, and pregiven container (i.e., levels) toward a concept of scale as a socially constructed and therefore contested and continually evolving dimension of spatiality. Scale becomes a relational property that emerges as a product of social struggles for power and control (Brenner 2001). The politics of scale is therefore understood as "the creation of a level of resolution at which phenomena are deemed understandable" (Kelly 1997:152). The concept of scale refines our approach to transnational migrant politics for two reasons. As a spatial property the notion of scale suggests that nominally similar types of transnational institutions may generate different kinds of institutional connectedness because of the varying "levels" at which they make issues understandable. As a relational property the notion of scalar politics dovetails with the concept of institutional interlocutors because it foregrounds comprehension and translatability of agendas as an important element of political practice.

\section{COMPARATIVE PERSPECTIVES ON SALVADORAN GRASSROOTS ORGANIZING}

There are an estimated 2.9 million migrants from El Salvador in North America, with significant concentrations in Los Angeles, Washington, New York City, Toronto, Atlanta, and Houston, among others (Ministerio de Relaciones Exteriores 2006). The structural dislocations, patterns of movement, and settlement of contemporary Salvadoran migration are well documented (Hamilton and Chinchilla 1996). In the late '70s the country was engulfed in civil war with the U.S.-backed Salvadoran government and armed forces in open battle against the guerrilla insurgency of the Frente Farabundo Martí para la Liberación Nacional (FMLN). The violence and the social and economic disruptions associated with warfare prompted an international refugee exodus that quickly overtook 
the country's century-old regional and seasonal labor migration system (Edwards and Siebentritt 1991). Cold war geopolitics had a significant impact both on the Salvadoran refugee flow and on the contexts of reception that organized the settlement process (Ferris 1987; Zolberg, Suhrke, and Aguayo 1989).

Salvadorans' largely involuntary departure from their country generated dense circuits of exchange between people and institutions in settlement cities and El Salvador. There is considerable evidence to confirm that Salvadoran family relations (Menjívar 2000; Landolt and Da 2005), labor market experiences and entrepreneurial activities (Mahler 1995; Landolt 2001), religious life (Menjivar 1999), youth transitions to adulthood (Zilberg and Lungo 1999), and political practices (Popkin 2003; Baker-Cristales 2004) were and continue to be organized through interlocking social networks that cross national borders.

My comparative analysis of Salvadoran political practice focuses on the relationships between migrant and nonmigrant organizations and on the kinds of grassroots migrant activism that emerges out of these dialogues. It is based on findings from two collaborative research projects in which I participated between 1996 and 2006. The first project was called the Comparative Immigrant Entrepreneurship Project (CIEP) and was directed by Alejandro Portes and Luis Eduardo Guarnizo. It developed the first quantitative survey to address the individual-level determinants of transnational activities. From the CIEP research, I use data from key informant interviews conducted between 1996 and 1998 in Los Angeles, Washington, and El Salvador with migrant and nonmigrant entrepreneurs, community leaders, and political activists (N 120) and from the structured survey of transnational actors that was applied in Washington, Los Angeles, and multiple urban and rural locations in El Salvador (N 150).

The second project was called "Social Cohesion and International Migration in a Globalizing Era: Transnational Solidarities and Newcomer Incorporation in Canada" and was directed by Michael Lanphier. As part of that project, three coinvestigators formed the Latin American Research Group (LARG) to study various aspects of the Chilean, Salvadoran, Guatemalan, and Colombian settlement experience in the Greater Toronto Area (GTA). ${ }^{2}$ Focus group interviews conducted in 2004 and 2005 collected information about the history, agendas, and transnational versus settlement orientations of civic organizations formed by Latin Americans in the GTA. For this article I draw on information gathered in the Salvadoran and Canadian solidarity and refugee rights and advocacy group interviews (N 25).

I analyze the findings using a multilevel comparative approach that takes into account both within- and between-group differences (Przeworksi and Teune 1970). I establish two axes of similarity and difference to account for variation in the process of community formation and the character of migrant grassroots organizing. First, I examine the national and city-level contexts of reception that organize Salvadoran migration and settlement. The cross-national comparison highlights the ways in which state policy frames migration patterns and the early settlement experience. In turn, I consider how city-level contexts of reception intersect with patterns set by national-level dynamics to frame the networks and narratives that organize and undergird group identity. 
Second, I trace the institutional dialogues that develop between migrant and nonmigrant organizations during the civil war and in the postwar period. I examine the variable development of relations between Salvadoran migrants and three types of organizations that are present in different forms in Los Angeles, Washington, and Toronto: FMLN organizations, nonmigrant solidarity groups, and immigrant settlement organizations. I also consider the relationship between migrants and the Salvadoran state. My analysis focuses on cross-city differences in the IOS and dialogues between migrants and nonmigrant organizations to explain variation in the territorial and scalar orientation of migrant politics. My goal is not to provide an exhaustive description of all migrant organizations, nor of all of the different institutional dialogues that emerge in each location. Rather, I present a set of patterns that are illustrative and permit me to advance a theoretically informed explanation of spatial variation in migrant grassroots political practice.

\section{CONTEXTUALIZING SALVADORAN COMMUNITY FORMATION}

The national contexts of reception that organize Salvadoran migration to Canada and the United States are marked by a significant variation (Garcia 2006). There are also considerable differences in the local contexts of reception of Los Angeles, Washington, and Toronto. The character of state policies and the resulting modes of entry and migrant status upon entry for each country, as well as distinct city-level conditions, produce different combinations of social network structures in each settlement city. These patterns are summarized below.

In the United States the government's insistence on framing the regional conflicts within the geopolitics of the cold war overshadows all other political or humanitarian considerations. Salvadorans entering the United States encounter a hostile federal government that refuses to recognize El Salvador as a refugee-producing country (Ferris 1987; Stanton-Russell 1995). Salvadorans' largely undocumented entry into the United States follows a classic pattern of clandestine chain migration that promotes the formation of social networks of mutual aid among friends, extended kin, and paisanos or individuals from the same place of origin (Mahler 1995; Menjívar 2000).

In Los Angeles and Washington, DC, the physical layout of the city encourages the formation of residential settlement patterns and daily rounds that reinforce the endogenous patterns of sociability imposed by the migration process. Decentralization and polycentric urban sprawl coupled with extensive freeways and a dysfunctional public transportation system result in dispersed clusters of social and economic activity. In this context, Salvadoran home-to-work routines remain localized and circumscribed. The physical landscape encourages interaction within neighborhoods and discourages social contact across locations. The urban-built environment thus reinforces premigration relationships and social obligations and facilitates the revival of home country institutions and activities in settlement locations.

By contrast to the United States, Salvadoran migration to Canada does not tap into previous labor migration networks and is organized as a state-mediated refugee flow. 
Pressured by the national refugee rights lobby and the United Nations, the Canadian government reluctantly agreed to establish measures for the regulated and authorized entry of Salvadoran and later Guatemalan refugees (Garcia 2006). This included allowing Salvadorans facing deportation in the United States to make an asylum application in Canada. Fifty-eight percent of Salvadorans migrants to Canada have entered as convention refugees selected abroad and an additional 11 percent applied for asylum at the United States-Canada border (Landolt 2007).

In Canada, the resettlement of asylum seekers and both government- and privately sponsored refugees is typically carried out through immigrant settlement agencies. Informal mutual aid networks among Salvadorans emerge as a complement to statefunded settlement arrangements. Instead of social exchange among covillagers or extended kin, social networks of mutual support connects clusters of Salvadorans who typically have no premigration relationship. Casual encounters at immigration offices, settlement agencies, and refugee-sponsoring organizations often serve as the point of departure for the formation of friendship networks. Furthermore, Salvadoran Torontonians exhibit relatively dispersed settlement patterns. Together, the near absence of chain migration networks that in the two U.S. cities encourage residential concentration, the strong role of the state and social service agencies in organizing settlement, and the tendency toward dispersal and movement make it difficult for Salvadoran conationals to establish stable social relations. There is little basis for the revival of home village loyalties and much less for the reconstitution of home country institutions.

Variation in the ways Salvadorans are discursively located in Toronto, Washington, and Los Angeles are reflected in the differentiated production of nationally distinct and locally specific narratives of community identity. In the United States, the state and specifically the Immigration and Naturalization Service (INS) engages Salvadorans within a legal framework of interdiction, detention, and deportation and in so doing cloaks the refugee flow in a criminalizing narrative. Salvadorans in this case are constructed by the state as illegal labor migrants-as foot people or more pejoratively as wetbacks. Salvadorans are never defined as political refugees escaping violence. This framing of the situation pushes Salvadorans to distance themselves from the political violence that is constitutive of their immigrant experience.

In Canada, Salvadorans are represented and treated like legitimate political refugees by the state and by institutions and individuals in both progressive and mainstream social circles. This discursive context reinforces the types of shared identification generated by social network patterns. In Canada, state-mediated migration and settlement makes village or neighborhood-level identities and social ties irrelevant to the production of group identity. It tends instead to exalt and link together two points of reference for the construction of identity: the Salvadoran nation and the refugee flight from the political violence of an authoritarian state.

In turn, each city context further differentiates Salvadoran settlement experiences. Los Angeles, for example, has a dramatic immigration history. In just three decades, it changed from being a city populated by whites with roots in the small towns of the Midwest to a global metropolis. Over 30 percent of the local population is now foreign 
born, of which 40 percent is Mexican and 6 percent is Salvadoran. In addition, approximately one-third of the local labor force-including many Latin Americans-is undocumented (Bobo et al. 2000). The local political agenda-whether pro or antiimmigrant-necessarily reflects the fact that Latin Americans are an indomitable social force with considerable political clout. Key issues that affect Salvadorans-immigration status, border politics, and precarious work and the exploitation of undocumented workers-are necessarily on the political agenda.

Washington offers a contrasting case. Historically, the absence of industrial production and the fact that the U.S. government was the city's largest employer shut foreigners out of the local labor market. However, in the '70s, changes in the urban economy prompted new labor demands and a corresponding growth of the immigrant population. Between 1980 and 2000 the foreign-born population increased by 220 percent (Pedraza and Rumbaut 1996). The city became home to a large concentration of Central Americans, the fourth largest group of Koreans in the United States, and the largest Ethiopian population outside of Africa (Repak 1995). Yet local politics have failed to reflect the concerns of the growing immigrant population and continue to be framed in biracial terms (Pedraza and Rumbaut 1996). Salvadoran leaders interviewed in Washington cite the case of the Office for Latino Affairs to demonstrate how Latinos have been shut out of local politics. In 1991, in the aftermath of a series of riots led by Salvadoran youth, Latinos demand greater participation in the existing political structure. The municipality responds with the creation of an Office for Latino Affairs and the Latino Civil Rights Task Force. Relations between these offices and the government were never clearly laid out. Established with soft money, by 1998 both organizations faced major budget cuts and were close to shutting down.

Toronto has a long history as an immigrant city and since the '70s has emerged as a self-consciously multicultural city (Anisef and Lanphier 2003). The foreign-born population has increased steadily, reaching over 40 percent by the year 2000, but no single source country or language group dominates the city's immigration flows (Preston, Lo, and Wang 2003). There is a high concentration of political refugees and exiles from Chile, Argentina, El Salvador, and Guatemala in the city of Toronto (Gilbert and Lee 1986; Goldring 2006). Latin American political refugees have established a significant political presence in the city and have played a role in defining the political priorities of the city's progressive social sectors (Goldring et al. 2006).

Together, structures of relations, flows of resources, and a shared cultural-symbolic order are cornerstones of community formation. The comparative presentation of patterns for a single migrant group highlights the importance of multitiered contexts of reception in the production of networks and narratives that sustain group identity formation. Together, state policy and its subtexts about national belonging are implicated in the production of the social networks of migration and settlement and in contouring the narratives a group draws on to establish a collective identity. In the United States, Salvadoran migration is organized through informal social networks, and there is a depoliticization of the migration narrative. Salvadoran refugees are discursively constructed as foot people and wetbacks. In Canada, state policy offers a more 
political reading of the Salvadoran migration process. But here the strong arm of the state (and its shadow immigrant settlement agencies) tends to pull Salvadorans apart and weakens the basis for constituting informal networks of social exchange (cf. Mitchell 2001).

Urban contexts interact with this national-level pattern. For instance, residential propinquity and shared personal histories of life before migration - the pattern found in Los Angeles and Washington-facilitates the regeneration of premigration social relations and serves to cement social exchange. In LA, the weight of the Latino presence grants Salvadorans different material and discursive possibilities for collective identity and network formation. In Toronto, the absence of chain migration networks and a tendency toward residential dispersal raises questions about the modes of sociability and social exchange that are sustainable among Salvadorans.

\section{THE LANDSCAPES OF SALVADORAN GRASSROOTS ACTIVISM, 1970s TO 1990s}

Over a period of 25 years, important changes have occurred in the institutional landscapes where Salvadoran migrants have been embedded. In the 1980s, the civil war in El Salvador and the politics of refugee asylum determined the IOS that framed Salvadoran grassroots activism, including the types of organizations that were present in each settlement city, their political priorities and strategies, and the nature of their relationship to the migrant population. Whereas in Canada relations between civil society organizations and the state were generally characterized by dialogue, information sharing, and collaboration, in the United States activism was framed as a direct confrontation with the state. This became an important source of difference in the IOS of each city and in the types of dialogues that were established between migrants and nonmigrant organizations.

During the 1980s, three types of institutions were established in each settlement city. First, organizations were created by the FMLN as part of its transnational fund-raising campaign and political-lobbying strategy, including organizations that worked directly with the migrant population and others that functioned as nonmigrant activist-run solidarity organizations (Gosse 1996). Second, a looser knit network of progressive secondary associations came out of the local labor movement, student groups, faithbased and community organizations, among others, to lobby government, organize education campaigns, and plan speaking tours for Salvadoran opposition leaders. Together, these two types of organizations constituted the Central American Solidarity Movement (Gosse 1988).

Third, the Sanctuary Movement focused on Salvadoran refugee asylum and settlement issues. Sanctuary was created by faith-based social activists as a direct response to the U.S. government's refusal to recognize Salvadorans and Guatemalans as legitimate asylum seekers. In 1982, churches working with Salvadorans along the United StatesMexico border declared their places of worship as refugee safe havens. They warned the INS to stay out or risk breaking sacred law (Golden and McConnell 1986). Toronto's 
refugee rights activists confirm that Canadian churches also participated in the Sanctuary Movement. Religious leaders and congregants traveled to U.S. detention centers and church safe havens to help refugees make an application for asylum in Canada and shuttled refugees across the United States-Canada border.

In the 1990s, the signing of the Peace Accords in El Salvador and the project of national reconstruction and reconciliation brought about dramatic changes in the institutional landscape of El Salvador, its migrant settlements, and the web of transnational relations that connected these different locations. The Sanctuary Movement, FMLN networks, and immigrant rights organizations were dissolved or forced to redefine their mandate, priorities, and strategies. For many, this involved a process of professionalization and bureaucratization and a shift away from rigidly partisan politics toward the formation of strategic alliances across a broader range of social sectors.

The national government of El Salvador, largely absent from Salvadoran settlements during the civil war, established an active presence in U.S. cities of Salvadoran concentration but remained noticeably absent in Canada. Soon after the signing of the peace, El Salvador's consular and embassy officials organized consultations with local community and business leaders. The government developed strategic alliances with migrant organizations to lobby the U.S. federal government for the regularization of Salvadorans' immigration status (Popkin 2003). In the year 2000, the state created the General Secretariat of Attention to the Community Abroad (DGACE, Spanish acronym). The extraterritorial policy shift was matched by rhetorical adjustment in which migrants were no longer labeled subversives and traitors, but rather distant brothers or hermanos lejanos, and were portrayed as long-distance members of the national community and lauded for sending the remittances that maintain the (national) family.

\section{Salvadoran Los Angeles ${ }^{3}$}

During this 25-year period, a defining feature of the Los Angeles institutional landscape is the centrality, resources, and political legitimacy of FMLN organizations. In the early 1980s, the FMLN selected Los Angeles as a coordinating hub for its North American advocacy work. A core group of FMLN cadres settled in the city. Over the years, this well-honed and influential cohort of political workers participated in a variety of citylevel, cross-sectoral initiatives. The group developed expansive and flexible social networks that tied FMLN cadres' explicitly transnational and partisan agenda into a range of social and political arenas.

The work of the Central American Refugee Centre (CARECEN), renamed the Central American Resource Centre in 1994, and El Rescate, organizations created by two different factions of the FMLN in the early '80s, is illustrative. CARECEN and El Rescate were established in the Salvadoran neighborhood of Pico-Union. Emergency settlement work was carried out on a shoestring budget, counting on the volunteer time of North American lawyers, religious workers, and university students among others, as well as the involvement of Sanctuary churches and solidarity movement activists. Along with 
settlement assistance, both CARECEN and El Rescate dedicated considerable resources to migrant political education, providing up-to-date information about the insurgency's war effort and organizing public education forums and cultural events. U.S. activists were also recruited into FMLN organizations. As a result, in a growing number of migrant and nonmigrant social circles, the idea of guerrilla warfare as a legitimate response to the social inequalities of Salvadoran society gained purchase. Local FMLN cadres were granted considerable authority, not simply as representatives of a transnational partisan organization, but also as community leaders.

Given their long-term commitment to frontline settlement work, both CARECEN and El Rescate were able to adjust their mandate in tune with the changing needs of Salvadoran Angelinos. Over the years, the multiplicity of issues taken on by the two organizations has included securing legal status for Salvadorans; mobilizing for the rights of precarious workers including street vendors, day laborers, and cleaners; offering life skills and public health workshops; and working with at-risk youth. They have learned to link the specific concerns of undocumented and impoverished refugees and migrants to broader political discussions taking place in Southern California, El Salvador, and elsewhere.

In Los Angeles, Salvadoran migrant grassroots activism is intertwined with the political work that comes out of FMLN-affiliated organizations such as CARECEN and El Rescate. Two examples capture the ways in which the institutional dialogue between migrants and FMLN-organizations frames political practice. The first case traces the rise of migrant-led hometown associations (HTAs) or comites de oriundos and suggests how Salvadoran Angelino grassroots organizing is able to articulate translocal and transnational scales of political engagement.

HTAs are commonly formed by friends and extended families from the same place of origin who organize fund-raising events to finance structural and social improvement projects in the members' place of origin. They are a type of collective, as opposed to family-based, remittance projects. The proliferation of Salvadoran HTAs, particularly in the postwar era, reflects the migrants' desire to uphold social obligations to nonmigrant kin and participate in El Salvador's reconstruction in ways that they deem relevant. While HTAs are typically run by a small core membership of between 5 and 20 individuals, comite social events can mobilize hundreds of people. These events help renew and strengthen relations among covillagers. As hypothesized, the continued viability of premigration relationships makes possible the formation of HTAs. These ties are sustained by ongoing chain migration and strengthened by informal social exchange.

El Rescate was quick to identify the overlap between its own transnational political agenda and those of paisanos intent on improving conditions in their home villages. In 1994 it brought together over 50 HTAs to form the umbrella group Communities United to Provide Direct Aid to El Salvador (COMUNIDADES). The original goals of COMUNIDADES were to facilitate the sharing of best practices among comites, to encourage HTAs to apply for nonprofit status, and to assist them with financial and administrative tasks. In the process, El Rescate emerged as an important bridge between HTAs and 
different institutions interested in the relationship between collective remittances and rural development, including North American academics, private foundations, international donor agencies, and the government of El Salvador.

The formation of COMUNIDADES by El Rescate set into motion a set of institutional relationships that culminated with HTAs as a relevant interlocutor of the Salvadoran government. In 1999 the government of El Salvador created the Social Investment Fund for Local Development (FIS-DL) and shortly thereafter the FIS-DL launched the United in Solidarity Program, which offers matching funds on a two-for-one basis for the kinds of collective remittance projects being developed by HTAs. The program hoped to encourage HTAs to fund-raise and apply for FIS-DL matching funds. COMUNIDADES served as the ideal bridge between HTAs and the United in Solidarity granting system. It could assist HTAs to make an application and offered the state access to increasingly professional comites.

The case of Salvadoran Angelino HTAs cut a complex path from translocal social obligations to participation in a state project through the transnational mobilization of resources for rural development. The steps along the way include premigration village-based social networks, precarious social exchange in Los Angeles, the proliferation of comites de oriundos, the creation of an umbrella organization that helps professionalize HTAs, and finally, the Salvadoran state's extraterritorial invitation to participate in the national development process. The case of Salvadoran Angelino HTAs captures one way in which translocal grassroots organizing embedded in village loyalties and kinship ties can be articulated to transnational political arenas of decision making by way of a strategically positioned interlocutor (El Rescate). Discursively, a sense of translocal social obligations to a place of origin dovetails with a state narrative of transnational collaboration that hinges on the obligations of the hermano lejano.

The second example focuses on the LA riots of 1992 to consider how Salvadoran Angelinos engaged in local politics in ways that reflected both an assimilationist and transnational orientation. In the aftermath of the LA riots, city officials and neighborhood activists shifted their social and political priorities. New political alliances and funding priorities emerged. Organizations like El Rescate and CARECEN participated actively in citywide conversations about the root causes of the riots. Thus, groups with a history of denouncing human rights abuses in El Salvador and along the United States-Mexico border turned to denouncing human and civil rights abuses that were perpetrated by the INS, the Los Angeles Police Department, and the National Guard. Joining cross-sectoral postriot coalitions and expanding into interethnic collaborative projects brought Central Americans into contact with pan-Asian and African-American organizations.

The LA riots shifted the IOS that had previously framed Salvadoran migrant politics. These interinstitutional collaborations helped consolidate a turn in Salvadoran Angelino politics toward the ethnic and racialized identities and solidarities that are currently a defining element of the immigrant experience in the United States (Baker-Cristales 2004). The Salvadoran response produced an expansion in the territorial orientation of 
grassroots organizing from a narrowly transnational focus to one that bridged transnational and assimilationist agendas. This was reflected both in the types of interinstitutional collaboration and the narratives of racialized belonging that undergirded these efforts.

\section{Fragmented Loyalties in Washington, DC}

The institutional landscape in which Salvadorans are embedded in Washington, DC lacks the overarching organizational coherence and strong core leadership present in Los Angeles. Two factors account for this situation including the character of FMLNmigrant relations and the dominant role of faith-based organizations in the Salvadoran settlement process.

In Washington, relations between the FMLN and the migrant population have been quite limited and narrow in scope. A local office of CARECEN offered emergency settlement assistance but developed little political education work in the city. This pattern continued in the postwar era. The FMLN focused on the creation of North American membership-based solidarity organizations able to coordinate nationwide lobbying and education campaigns in line with the strategic priorities of the insurgency. The fact that Washington is the nation's capital helps explain this focus. However, social workers in Washington indicated that the FMLN attempted to mobilize the migrant population but failed. They suggested that Salvadorans in Washington were deeply suspicious of explicitly political projects in general and of the FMLN in particular. This is explained in part by the particularities of Salvadoran migration to Washington, which began before the civil war and was largely from regions of eastern El Salvador where the FMLN had a weaker political presence and where state counterinsurgency was quite effective.

In Washington, faith-based activists tied to the Sanctuary Movement played a dominant role in Salvadorans' early settlement process. For instance, Casa del Pueblo United Methodist Church and its affiliated Clínica del Pueblo were established in 1983 to offer emergency settlement assistance. Their original membership included Sanctuary Movement activists, FMLN sympathizers and party members, as well as volunteer health care professionals. The Clínica del Pueblo grew from a one-room clinic serving undocumented Salvadorans into a multipurpose, multilingual health project. A second case is CASA of Maryland, which was founded in 1985 by Central and North Americans. Originally established to meet the specific needs of Central American refugees, it now serves immigrants from virtually every country in Latin America as well as Africans, Asians, and U.S. citizens.

In both cases, informal emergency assistance mobilized the resources of local congregations committed to the humanist politics of the Sanctuary Movement. Their work served as the basis for the creation of institutionally stable, bureaucratized professional social service agencies. The changing needs of Salvadorans have prompted a diversification of services to include youth at risk, the rights of precarious workers (day laborers program), tenants' rights, business and life skills, and public health concerns. Given the multiethnic and multilingual character of Washington's immigrant neighborhoods, 
both organizations have also expanded the demographic scope of their work. However, even as they develop new arenas of social work and a broader client-base, their agenda remains oriented toward local settlement issues. Border-crossing orientations do not figure prominently in the social mandate or institutional alliances maintained by these two organizations.

The first example of Salvadoran grassroots activism recounts efforts by a cluster of community organizers to constitute a Salvadoran-American political action committee (PAC) in Washington. In the post-civil war era, community leaders, many of them employed in social and immigrant service agencies, discussed the possibility of developing a distinctly Salvadoran-American political platform. This was to be defined in terms of broadly construed citizenship rights including issues such as legal regularization, the vote, and workers' rights and would draw on the local leaders' contacts with other Salvadoran organizations in the United States. Multiple, often disparate, mandates emerged out of these discussions, and multiple resource-strapped PACs were formed with little effect.

In this case, community activists failed to constitute a cohesive network of partners and were unable to agree on a coherent if somewhat pluralistic Salvadoran-American political agenda. Furthermore, the project of creating a Salvadoran-American PAC did not resonate with the priorities of the local migrant population. It is also met with limited interest or support among other immigrant groups and the dominant AfricanAmerican force in local politics.

The second example recounts the formation of HTAs. The point of departure for the rise of Washington HTAs is similar to the pattern found in Los Angeles. In the postwar era, small cliques of covillagers organized collective remittance projects geared toward improvements in their places of origin. Much like Los Angeles, Washington comités tended to depend on a narrow set of trans-local personal contacts and varied in size and stability. However, unlike Los Angeles, in Washington HTAs were guarded about their projects and made no effort to share best practices or organize themselves into any sort of broader collective. The fear of politics and the desire to remain "apolitical" sabotaged intergroup collaboration. There was also considerable suspicion that HTAs were merely instruments for the personal advancement of a few. Furthermore, on different occasions, both successful and failed HTA initiatives have been associated with institutional fragmentation. Hometown organizations have at times splintered into neighborhood- or canton-based organizations.

In Washington no institution had the political authority or will to play the coordinating role that El Rescate played for HTAs in Los Angeles. The comites worked in isolation, competing with each other for resources and public recognition. While HTAs maintained contact with local embassy officials, this did not generate an institutional dialogue between migrants and the Salvadoran state that could alter the parochial scale through which migrants interpreted their work. Contact with the embassy simply served to affirm the social status of individual comite members. The articulation of translocal village concerns with a national agenda of reconstruction that existed in Los Angeles remained absent in Washington. Quite to the contrary, there was a tendency toward the 
disarticulation of village-level points of convergence toward even more particularistic geographies.

\section{Exile and Social Justice in Multicultural Toronto ${ }^{4}$}

The Toronto institutional landscape and specifically the FMLN and faith-based organizations' relationship to Salvadoran migrants is quite different from the patterns found in the United States. As discussed earlier, this is in large part a function of the Canadian state's distance from the Central American conflict and its recognition of El Salvador as a refugee-producing country. First, in this city, relations between Salvadoran migrants and local FMLN organizations were conjunctural and instrumental. FMLN activism actually began and peaked in the '70s, prior to the arrival of the refugees, and focused on the establishment of working partnerships with Canadian academics, unions, and human rights organizations. By the 1980s, the FMLN had relegated Toronto to a secondtier status within its transnational advocacy work and, given the possibility of recognition and dialogue by the Canadian state, the FMLN focused on the development of contacts with Canadian solidarity organizations that could facilitate a diplomatic relationship between the insurgency and the Canadian government. Second, barring the need for emergency settlement assistance that existed in the United States, faith-based groups focused on getting asylum seekers to a Canadian border, sponsoring refugees, and helping the migrants with government paperwork, legal aid, and employment searches, among other things.

Tracing the activities of a single cluster of Salvadoran refugees provides a lens into the patterns of grassroots organizing that developed in Toronto. In the mid-' $80 \mathrm{~s}$, a Salvadoran mutual aid organization was started by several groups of extended kin and friends who came together under the aegis of a Canadian religious organization involved in refugee sponsorship and settlement work. The group was bound together by a transnational narrative of political refugeeship, by their belief in the need for radical social change in El Salvador, and by a commitment to political diversity and tolerance. The association's early activities focused on settlement needs, preserving cultural identity and recovering from the psychosocial traumas of the civil war. From weekly meetings to share information about the Canadian system, the group branched out into different arenas-popular theatre, a folkloric music group, a soccer team, and children's workshops, among other activities. It also collaborated with the local FMLN organizations, Canadian solidarity groups, and Latin American exile organizations in clearly defined, short-term activities such as public education forums.

The mutual aid association proved to be fertile territory for the development of a range of collective projects with varying territorial orientations and scales of engagement. It served as a staging ground for a woman's group, an annual family summer camp retreat, the first steps toward the establishment of a Salvadoran housing cooperative, and continual fund-raising and advocacy on behalf of organizations and projects in El Salvador. Toward the end of the civil war, activists and community leaders associated with the mutual aid cluster began to identify nonmilitary opposition groups in El Salvador with whom they might collaborate. This included the National University of El 
Salvador, which had been devastated by the army and kept under military cordon throughout the civil war, and the communities of refugees who were repatriating from Honduras back to El Salvador. The principles of people-to-people or grassroots development assistance and not loyalties to a village of origin organized these transnational relationships. The networks that sustained the projects were forged through political ties and personal friendships and sustained by an inclusive narrative of social justice. It was a narrative in which non-Salvadorans could and did participate.

Finally, the conspicuous absence of the Salvadoran government from the Toronto social landscape affected the ways in which Salvadorans conceptualized their participation in the postwar reconstruction of their country of origin. While Salvadoran organizations in U.S. cities with a history of FMLN activism learned to work strategically with the Salvadoran government, in Toronto the institutional contacts and narratives of engagement sustained by migrants reflected a very linear expansion of the ties and commitments the group had established during the civil war. In particular, they continued to work with institutions that, in their estimation, had not abandoned the project for social justice that originally guided the country's popular insurgency. Indeed, Salvadorans in Toronto framed their national project of reconstruction in terms of a political cartography that explicitly excluded the Salvadoran state as a legitimate interlocutor.

\section{Comparing Patterns of Salvadoran Grassroots Activism}

Each of the three cities of Salvadoran settlement presents a distinct pattern of political practice characterized by variation in the territorial and scalar orientations of migrant activism. My analysis links this spatial variation in political practice to two sets of related factors including the local context of reception which gives rise to distinct networks and narratives of group identity, and the city-level IOS that favors some institutional dialogues over others.

National- and city-level contexts of reception intersect to produce three migration and early settlement experiences. Each brings with it the production of a distinct Salvadoran group identity. In Washington and Los Angeles, chain migration networks push migrants toward village-level loyalties, identities, and political priorities. This tendency is exacerbated by the social balkanization produced by the built environment. The two U.S. cases also diverge because of each city's distinct immigration traditions. Whereas Latinos are a predominant presence in Los Angeles, Washington, DC has a much more recent and heterogeneous immigration tradition. This demographic difference impacts the agenda of local politics and specifically the relevance of Salvadorans' issues for the broader population. In Toronto, in contrast, a state-mediated refugee flow, the tendency toward residential dispersal of recent immigrants, and the local politics of multiculturalism lead to the formation of a Salvadoran migrant community that is organized around loosely networked postmigration friendship clusters. It also facilitates the emergence of a group narrative that emphasizes national as opposed to village-level loyalties and political refugeeship as a legitimate group identity.

Each city also presents a distinct IOS. Differences in Canadian and U.S. state policy are a determining factor in the definition of the IOS. Given the U.S. government's 
unwillingness to recognize El Salvador as a refugee-producing country and its criminalization of Salvadoran migrants, in Los Angeles and Washington, settlement work emerges as a political flash point. It encourages radical grassroots activism that brings together a broad spectrum of civil society organizations and facilitates the establishment of an intense relationship between these and the migrant population. In contrast, Canadian civil society organizations involved in settlement work serve as a friendly backdrop to Salvadoran migrant activism but not as interlocutors or allies with a shared and urgent political agenda. Settlement does not generate the kind of cross-sectoral grassroots activism seen in Los Angeles and Washington, DC.

A focus on the behavior of specific civil society organizations makes more pronounced cross-city differences in the IOS. The FMLN plays a different political role in each city. In Los Angeles, FMLN organizations sustain a long-term relationship with the migrant population that begins with emergency settlement assistance and evolves into a multi-issue dialogue of collaboration. In Washington the FMLN fails to capture the migrant population, in part because of the distinct characteristics of Washington Salvadorans who tend to avoid partisan affiliations, but also because the local FMLN focus is on national-level political campaigns. In Toronto, the FMLN is much less active and again, its political priorities are different. Rather than emergency settlement assistance, which is largely taken care of by the state-funded settlement agencies, the FMLN focuses on relations with Canadian solidarity organizations able to help the insurgency find a receptive audience in parliament.

The faith-based organizations of each city also relate differently to the migrant population. In Los Angeles, the Sanctuary Movement is overshadowed by the FMLN. In Washington, faith-based groups play a central role in settlement work and facilitate the constitution of social service agencies that serve the growing needs of the migrant population. Over the years, agencies have evolved to meet the needs of their increasingly heterogeneous immigrant constituency. In this scenario, the specificity of a Salvadoran migrant agenda is lost. In Toronto, faith-based groups also play a primary role in migrant settlement. They constitute a receptive audience or backdrop to autonomous Salvadoran activism, but not an active political ally.

The three spatially variable patterns can be summarized as follows. In Los Angeles, the FMLN plays a central role in framing migrant activism in general and its spatial trajectory in particular. In the ' 80 s and '90s, it was often difficult to distinguish between the migrant and the partisan FMLN agenda. This relationship enabled migrant organizations, HTAs in particular, to articulate translocal and transnational scales of political engagement. The Salvadoran migrant political agenda did not stagnate and matured with the changing political climate. In the context of the LA riots, for instance, Salvadoran activists were able to weave together the assimilationist and transnational concerns of the migrant population and successfully insert them into local political platforms.

In the case of Washington, DC, the territorial and scalar orientations of Salvadoran political practice are comparatively quite fragmented. Assimilationist and transnational orientations remain distinct. This is evidenced by the fact that social service agencies do 
not incorporate Salvadorans' transnational priorities into their work. Indeed, Salvadorans' political presence in the city is quite weak. There is a failure to consolidate a coherent Salvadoran political agenda, as well as an inability to break past the AfricanAmerican-dominated power structure that frames city politics. The migrants' bordercrossing projects remain translocal and there is a tendency for the disarticulation of home village notions of collective life toward more parochial scales of social obligation such as the neighborhood or canton. Migrants define their political and social priorities in terms of a very parochial set of group loyalties. There is no evidence of a transnational agenda.

Finally, in Toronto, Salvadoran grassroots organizing is undergirded by a collective narrative that reflects a simultaneity of transnational and assimilationist orientations and a national scale of engagement. In the postwar era, the absence of the Salvadoran state from the Toronto landscape fed into the existing narrative of oppositional politics. Transnational participation in reconstruction precluded dialogue with the state as the group's relatively stable social justice agenda determined their selection of legitimate transnational interlocutors. Institutionally, however, there was a tendency toward bifurcation, where transnational and assimilationist projects were undertaken through distinct organizational arrangements and drew upon different interlocutors depending on the specific activity. The kind of interwoven agendas evident in Los Angeles is absent. Echoing the situation in Washington, Salvadorans in Toronto have also been unable to insert their Salvadoran-specific agenda into the local political landscape.

To summarize and explain spatial variation in migrant activism, I have traced how each city offers a distinct pattern of conditions, a result of the interaction between the construction of context-contingent group identities and local IOSs. The IOS contours the political priorities and organizational strategies of migrants and nonmigrants alike. The networks and narratives that organize migrant group identity guide the formulation of a political agenda, the identification of legitimate interlocutors, and the terms of reference for these dialogues and strategic alliances.

\section{CONCLUSIONS}

Scholars have noted the importance of social relations and social formations constituted without territorial propinquity. The number and variety of nonstate actors that now sustain meaningful symbolic and material ties across the borders of nation-states is growing. International migrants, social movement activists, entrepreneurs, and religious figures are building social relations, institutions, and social formations that bridge distances and tie together people and institutions embedded within different nationstates. In this context, we find a sociospatial shift in the ways in which group identities are constituted, shared political agendas are defined, and strategies of collective action are consolidated and carried out.

Transnational migration scholarship has made considerable advances in its collective efforts at explaining the causes and consequences of this sociospatial transformation in the lives of international migrants. The concept of transnational social fields initiates a 
turn away from the detailed analysis and categorization of specific border-crossing practices undertaken by migrants toward theorizing the multidimensional domains of interaction embedded in two or more nation-states in which migrants carry out their lives. This conceptual shift bridges research on transnational migration to discussions taking place across the social sciences about the implications of globalization and transnationalism for social life. In turn, one of the strengths of immigration scholarship has always been its dedication to the detail-rich study of specific immigrant settlement experiences. As such, immigration scholarship's strength becomes fertile territory for theorizing the causes and consequences of transnationalism without losing sight of social relations, institutions, and local experiences.

My cross-city comparative analysis of Salvadoran refugee migration bridges propositions from mainstream immigration scholarship to the concepts of transnational social fields and the notion of scalar politics in order to explain variation in the constitution of migrant group identity and spatial variation in migrant political practice. I make three conceptual interventions to refine the study of immigrant politics. First, it is fairly standard in accounts of the immigrant settlement experience to suggest that contexts of exit and reception impact the character of migrant group identity. My analysis confirms this proposition and expands it to consider the interplay of national and city-level factors. In this case, national-level factors such as state-sponsored violence in the country of origin and variable state policies in the receiving countries is an important first step in the constitution of social networks of migration and social exchange. City-level variation in immigration traditions, ethnic and race relations, labor markets, and the built environment help refine the analysis of the Toronto case and help explain the different trends evidenced for Los Angeles and Washington, DC. This multilevel approach also confirms the importance of local specificity.

Second, I develop an approach to the concept of IOS that is cognizant of the sociospatial dimensions of social life. My analysis confirms that in the case of Salvadoran migrants, the relevant institutional landscape is not necessarily or always constrained by the standard units social science uses to bound and analyze social experience-the solidary community, the city, or the nation-state. Institutions in the country of origin and in other cities of conational settlement constitute part of the relevant institutional landscape. Thus, for example, the weak FMLN presence in Toronto or the FMLN focus on national-level campaigns in Washington, DC-features that impact the local IOS - only make sense if we consider FMLN strategies in Los Angeles and the broader transnational networks constituted by the guerrilla insurgency. Local decisions and resulting institutional conditions are thus a product of multiple locations.

I have proposed the concept of institutional interlocutors to foreground the dynamic and context-contingent character of political practice. The concept moves analysis away from the formulation of institutions as a backdrop to migrant politics toward the analysis of political practice as interactive relationships in which migrants identify legitimate interlocutors and develop strategies to generate mutual comprehension and advanced a (partially) shared agenda. These institutional dialogues constitute part of the 
socialization process that is so fundamental to any kind of politics. I have focused on relations between immigrants and other nonstate actors, which are often neglected in favor of a focus on endogenous, that is migrant-to-migrant, or vertical, state-migrant relations. In the case of Salvadoran migration to North America, while the receiving states clearly set the parameters of political possibility, the evidence confirms that the character of migrant activism is explained as an outcome of the relationships constituted between the refugees and two key nonstate actors: the FMLN and the Sanctuary Movement.

Finally, the idea of institutional interlocutors also helps explain the territorial and scalar variation of migrant politics. In the case of Salvadoran refugee migrants, transnational or assimilationist orientations emerge in each city via the interaction between migrant and nonmigrant organizations. The territorial orientations of political practice are best captured taking into account both narratives of belonging, which may include ties to both the home and host society, and institutional trajectories that identify the actual dialogues taking place-locally and across borders. The notion of scalar politics proposed by geographers, like the concept of institutional interlocutors, emphasizes that politics is in part about making issues understandable or relevant beyond one's own group. The comparison of Salvadoran HTAs in Los Angeles and Washington, DC highlights the importance of taking scales into consideration. In this case, the group identity and priorities that motivate collective remittance projects varies in part because of differences in the combination of institutional interlocutors involved in the process. Whereas in Los Angeles COMUNIDADES facilitates the move from trans-local to transnational politics, in Washington, DC there is a disarticulation of hometown-level to more parochial sites of political engagement.

Indeed, without a consideration of scale, it appears that Salvadorans in Los Angeles and Washington undertake very similar types of grassroots projects. However, the meanings with which projects are imbued vary; while Los Angeles comites bridge village-level commitments to participation in a transnational project of rural reconstruction, in Washington, HTAs serve to strengthen personalistic ties to parochial geographies. In Toronto, grassroots development projects suggest an alternative pattern in which narrowly defined projects organized through friendship networks, such as the reconstruction of a university library, assume national and oppositional dimensions. The concept of scale thus offers a refined perception that may lead transnational scholarship out of less constructive debates about whether transnational practices are indeed transnational or simply translocal (cf. Waldinger and Fitzgerald 2004). As we pay more attention to socio-spatiality we can begin to explain when and why it is that border-crossing practices assume a transnational or a translocal scale.

\section{NOTES}

${ }^{1}$ I thank Luin Goldring, Barry Wellman, Peggy Levitt, and Cecilia Menjivar for their feedback on earlier versions of this article and the four external reviewers of TSQ for their incisive and critical input. 
${ }^{2}$ The LARG was formed by the author of this article, Luin Goldring (York University) and Judith Bernhard (Ryerson University). For more information on the LARG, go to http://www.yorku.ca/ cohesion/LARG/html/largindex2.htm

${ }^{3}$ For a detailed discussion of Salvadoran organizing in Los Angeles and Washington see Patricia Landolt (2000), "The Causes and Consequences of Transnational Migration: Salvadorans in Los Angeles and Washington, D.C.," 345 pages in Sociology, Baltimore, MD: Johns Hopkins University, especially chapters 4 and 5 .

${ }^{4}$ The discussion of Toronto is partially based on Landolt (2007).

\section{REFERENCES}

Anisef, Paul and Michael C. Lanphier. 2003. The World in a City. Toronto, Canada: University of Toronto Press.

Baker-Cristales, Beth. 2004. "Salvadoran Transformations: Class Consciousness and Ethnic Identity in a Transnatioanl Milieu." Latin American Perspectives 31:15-33.

Bauböck, Rainer. 1994. Transnational Citizenship: Membership and Rights in International Migration. Brookfield, VT: Edward Elgar.

Beck, Ulrich. 2000. "The Cosmopolitan Perspective: Sociology in the Second Age of Modernity." The British Journal of Sociology 51:79-107.

Bloemraad, Irene. 2005. “The Limits of de Tocqueville: How Government Facilitates Organisational Capacity in Newcomer Communities." Journal of Ethnic and Migration Studies 31:865-88.

Bobo, Lawrence, Melvin Oliver, James Johnson, and Abel Valenzuela, eds. 2000. Prismatic Metropolis: Inequality in Los Angeles. New York: Russell Sage Foundation.

Brenner, Neil. 2001. "The Limits to Scale? Methodological Reflections on Scalar Structuration." Progress in Human Geography 25:591-614.

Brettel, Caroline. 2003. "Bringing the City Back In: Cities as Context for Immigrant Incorporation.” Pp. 163-95 in American Arrivals: Anthropology Engages the New Immigration, edited by Nancy Foner. Santa Fe, NM: School of American Research.

Edwards, Beatrice and Gretta Tovar Siebentritt. 1991. Places of Origin: The Repopulation of Rural El Salvador. Boulder, CO: Lynne Rienner Publishers.

Faist, Thomas. 2000. The Volume and Dynamics of International Migration and Transnational Spaces. New York: Oxford University Press.

Ferris, Elizabeth. 1987. The Central American Refugees. New York: Praeger Press.

Garcia, Maria Cristina. 2006. Seeking Refuge: Central American Migration to Mexico, the United States and Canada. Berkeley: University of California Press.

Gieryn, Thomas F. 2000. "A Space for Place in Sociology.” Annual Review of Sociology 26:463-96.

Gilbert, Jorge and Mario Lee. 1986. The Bridge between Canada and Latin America. Coquitlam, BC: Two Thirds Editions.

Glick-Schiller, Nina. 2005. "Transnational Social Fields and Imperialism.” Anthropological Theory 5:439-61.

Gold, Steven. 2002. The Israeli Diaspora. New York: Routledge.

Golden, Renny and Michael McConnell. 1986. Sanctuary: The New Underground Railroad. Maryknoll, NY: Orbis Books.

Goldring, Luin. 2006. "Latin American Transnationalism in Canada: Does It Exist, What Forms Does It Take, and Where Is It Going?” Pp. 337-78 in Transnational Identities and Practices in Canada, edited by Vic Satzewich and Lloyd Wong. Vancouver, Canada: University of British Columbia Press. 
Goldring, Luin, Patricia Landolt, Judith Bernhard, and Martha Barriga. 2006. "Toronto Hispano, Toronto Latino: Latin American Institutional Community Development in the Greater Toronto Area (1973-2005)." Pp. 58-71 in Ruptures, Continuities and Re-Learning: The Political Participation of Latin Americans in Canada, edited by Daniel Schugurensky and Jorge Giginiewicz. Toronto, Canada: OISE, Transformative Learning Centre.

Gosse, Van. 1988. " 'The North American Front': Central American Solidarity in the Reagan Era." Pp. 11-50 in In Reshaping the US Left: Popular Struggles in the 1980s, edited by Mike Davis and Michael Sprinker. New York: Verso Books.

—. 1996. "'El Salvador Is Spanish for Vietnam': A New Immigrant Left and the Policies of Solidarity." Pp. 302-30 in The Immigrant Left in the United States, edited by Paul Buhle and Dan Georgakas. Albany: State University of New York.

Halle, David, ed. 2003. New York \& Los Angeles: Politics, Society, and Culture in Comparative View. Chicago, IL: University of Chicago Press.

Hamilton, Nora and Norma Stoltz Chinchilla. 1996. "Global Economic Restructuring and International Migration: Some Observations Based on the Mexican and Central American Experience." International Migration 34:195-227.

Itzigsohn, José and Silvia Giorguli Saucedo. 2001. "Immigrant Incorporation and Sociocultural Transnationalism." International Migration Review 36:766-99.

Jessop, Bob. 2005. "Gramsci as a Spatial Theorist." Critical Review of International and Political Philosophy 8:421-37.

Joppke, Christian and Ewa Morawska. 2003. Toward Assimilation and Citizenship: Immigrants in Liberal Nation-States. Basingstoke, England: Palgrave Macmillan.

Keck, Margareet E. and Kathryn Sikkink. 1998. Activists beyond Borders. Advocacy Networks in International Politics. Ithaca, NY: Cornell University Press.

Kelly, Philip. 1997. "Globalization, Power and the Politics of Scale in the Philippines." Geoforum 28:151-71.

Kivisto, Peter. 2003. "Social Spaces, Transnational Immigrant Communities, and the Politics of Incorporation." Ethnicities 3:5-28.

Koopmans, Ruud. 2005. "The Missing Link between Structure and Agency: Outline of an Evolutionary Approach to Social Movements.” Mobilization: An International Journal 10:1733.

Kurien, Prema. 2001. "Religion, Ethnicity and Politics: Hindu and Muslim Indian Immigrants in the United States." Ethnic and Racial Studies 24:263-93.

Landolt, Patricia. 2000. "The Causes and Consequences of Transnational Migration: Salvadorans in Los Angeles and Washington, D.C.” Ph.D. diss., Johns Hopkins University, Baltimore, MD.

— . 2001. "Salvadoran Economic Transnationalism: Embedded Strategies for Household Maintenance, Immigrant Incorporation, and Entrepreneurial Expansion." Global Networks: A Journal of Transnational Affairs 1:217-41.

- 2007. "The Institutional Landscapes of Salvadoran Refugee Migration: Transnational and Local Views from Los Angeles and Toronto." Pp. 286-309 in Organizing the Transnational: The Experience of Asian and Latin American Migrants in Canada, edited by Luin Goldring and Sailaja V. Krishnamurti. Vancouver: University of British Columbia Press.

Landolt, Patricia and Wei Wei Da. 2005. "The Spatially Ruptured Practices of Transnational Migrant Families: Lessons from the Case of El Salvador and the People's Republic of China." Current Sociology 53:625-53.

Lefebvre, Henri. 1991. The Production of Space. Oxford, England: Blackwell. 
Levitt, Peggy. 2004. "Redefining the Boundaries of Belonging: The Institutional Character of Transnational Religious Life." Sociology of Religion 65(1):1-18.

Levitt, Peggy and Nina Glick-Schiller. 2004. "Conceptualizing Simultaneity: A Transnational Social Field Perspective on Society." International Migration Review 38:1002-39.

Mahler, Sarah. 1995. American Dreaming: Immigrant Life on the Margins. Princeton, NJ: Princeton University Press.

_ 1998. "Theoretical and Empirical Contributions towards a Research Agenda for Transnationalism." Pp. 64-101 in Transnationalism from Below, edited by Michael Peter Smith and Luis Eduardo Guarnizo. New Brunswick, NJ: Transaction Publishers.

Menjivar, Cecilia. 1999. "Religious Ties and Institutions: A Case Study of Catholic and Evangelical Salvadoran Immigrants.” International Journal of Politics, Culture, and Society 12:589611.

Menjívar, Cecilia. 2000. Fragmented Ties: Salvadoran Immigrant Networks in America. Los Angeles: University of California Press.

Ministerio de Relaciones Exteriores. 2006. "Comunidades Salvadoreña en el Exterior." Government of El Salvador.

Mitchell, Katharyne. 2001. "Transnationalism, Neo-Liberalism, and the Rise of the Shadow State." Economy and Society 30:165-89.

Ostergaard-Nielsen, Eva. 2003. "The Politics of Migrants' Transnational Political Practices." International Migration Review 37:760-86.

Pedraza, Silvia and Ruben G. Rumbaut. 1996. Origins and Destinies: Immigration, Race and Ethnicity in America. Belmont, CA: Wadsworth.

Popkin, Eric. 2003. "Transnational Migration and Development in Postwar Peripheral States: An Examination of Guatemalan and Salvadoran State Linkages with Their Migrant Populations in Los Angeles." Current Sociology 51:347-74.

Portes, Alejandro and József Böröcz. 1989. "Contemporary Immigration: Theoretical Perspectives on Its Determinants and Modes of Incorporation." International Migration Review 23:60630.

Portes, Alejandro and Ramón Grosfoguel. 1994. "Caribbean Diasporas: Migration and Ethnic Communities." Annals, AAPSS 533:48-69.

Preston, Valeria, Lucia Lo, and Shuguang Wang. 2003. "Immigrants' Economic Status in Toronto: Stories of Triumph and Disappointment." Pp. 192-260 in The World in a City, edited by Paul Anisef and Michael C. Lanphier. Toronto, Canada: University of Toronto Press.

Przeworksi, Adam and Henry Teune. 1970. The Logic of Comparative Social Inquiry. New York: Wiley-Interscience.

Repak, Terry. 1995. Waiting on Washington: Central American Workers in the Nation's Capital. Philadelphia, PA: Temple University Press.

Rogers, Reuel R. 2006. Afro-Caribbean Immigrants and the Politics of Incorporation: Ethnicity, Exception or Exit. New York: Cambridge University Press.

Schrover, Marlou and Floris Vermeulen. 2005. "Immigrant Organizations." Journal of Ethnic and Migration Studies 31:823-32.

Soysal, Yasemin. 1994. Limits of Citizenship: Migrants and Postnational Membership in Europe. Chicago, IL: University of Chicago Press.

Stanton-Russell, Sharon. 1995. "Migration Patterns of U.S. Foreign Policy Interests." Pp. 39-87 in Threatened Peoples, Threatened Borders: World Migration \& U.S. Policy, edited by Michael Teitelbaum and Myron Weiner. New York: W. W. Norton. 
Waldinger, Roger and David Fitzgerald. 2004. “Transnationalism in Question." American Journal of Sociology 109:1177-95.

Wimmer, Andreas and Nina Glick-Schiller. 2003. "Methodological Nationalism, the Social Sciences, and the Study of Migration: An Essay in Historical Epistemology." International Migration Review 37:576-610.

Zilberg, Elana and Mario Lungo. 1999. "Se han vuelto araganes? Juventud, migración e identidades laborales." Pp. 39-93 in Transformando El Salvador: Migración, Sociedad, y Cultura, edited by Mario Lungo and Susan Kandel. San Salvador, El Salvador: FUNDE.

Zolberg, Aristide, Astri Suhrke, and Sergio Aguayo. 1989. Escape from Violence: Conflict and the Refugee Crisis in the Developing World. New York: Oxford University Press. 